\title{
Archaeophytopathology of Phakopsora pachyrhizi, the Soybean Rust Pathogen
}

\author{
James S. Haudenshield and Glen L. Hartman, United States Department of Agriculture, Agricultural Research Service, and Department of \\ Crop Sciences, University of Illinois, Urbana 61801
}

\begin{abstract}
Haudenshield, J. S. and Hartman, G. L. 2015. Archaeophytopathology of Phakopsora pachyrhizi, the soybean rust pathogen. Plant Dis. 99:575-579.

Herbarium specimens are useful to compare attributes of the past to attributes of today and predictions into the future. In this study, herbarium specimens from 1887 to 2006 were used to identify Phakopsora pachyrhizi and $P$. meibomiae, the two known fungal species that cause soybean rust. Historically, these two species differed in geographic distribution, with $P$. pachyrhizi confined to Asia and Australia, and P. meibomiae confined to the Americas. In our analyses, herbarium specimens were used to determine whether it was possible to extract adequate useful DNA from the fungal structures. If present, quantitative PCR primers specific to $P$. pachyrhizi,

P. meibomiae, or to a third group inclusive of many rust species could be used to speciate the fungus. Of the 38 archival specimens, 11 were positive for $P$. pachyrhizi, including a 1912 specimen from Japan; 15 were positive for P. meibomiae, including a 1928 specimen from Brazil and two 1923 specimens from the Philippines; and 12 (including all African accessions) were negative for both species. Five specimens were positive in the more inclusive rust assay; all had been labeled as $P$. pachyrhizi and none were on soybean. These results demonstrate the feasibility of DNA genotyping in archaeophytopathological investigations.
\end{abstract}

Phakopsora pachyrhizi Syd. and P. meibomiae (Arthur) Arthur are two species of basidiomycete fungi that cause rust disease on a few leguminous crop plants, including soybean [Glycine max (L.) Merr.] and a number of other legume hosts belonging the subfamily Papilionoideae of the family Fabaceae $(10,11)$, which is one of the largest families of flowering plants. These fungi are obligate pathogens of their hosts and have not been successfully cultured on any artificial medium. No alternate hosts have been reported for either $P$. pachyrhizi or P. meibomiae (8), and it is possible that a host supporting the aecial reproductive stage is either rare or extinct. Thus, the airborne repeating propagules (urediniospores) are the only means of dissemination, and no sexual recombination is available to facilitate genetic exchange. However, a recent report indicated that urediniospore germ tubes could fuse and their nuclei could migrate into the complex hyphal network, suggesting that nuclear exchange may be possible among isolates (13). Several species of Phakopsora have been detected in the United States, including P. apoda, P. crotonis, P. gossypii, P. jatrophicola, and $P$. tecta (2), but until the arrival of $P$. pachyrhizi to the continental United States in 2004, none causing disease on soybean were present. $P$. meibomiae is known to cause soybean rust in Mexico and the Caribbean (8), but has not been reported in the United States. P. pachyrhizi was well known in the Far East and Oceania, and is also reported in African locations, where it impacts present-day soybean production (7), although as recently as 1984, the African Phakopsora populations were suggested to be of a possibly different forma specialis (8).

Comparisons of DNA extracted from herbarium specimens have been widely used for analyzing genomes in many different kinds

\section{Corresponding author: Glen L. Hartman, Email: ghartman@illinois.edu}

Trade and manufacturers' names are necessary to report factually on available data; however, the USDA neither guarantees nor warrants the standard of the product, and the use of the name by USDA implies no approval of the product to the exclusion of others that may also be suitable.

Accepted for publication 23 December 2014.

http://dx.doi.org/10.1094/PDIS-07-14-0772-SR

This article is in the public domain and not copyrightable. It may be freely reprinted with customary crediting of the source. The American Phytopathological Society, 2015. of biological samples (5), and more specifically to study fungal diversity in ancient documents (6) and to track historic migration of important plant pathogens like Phytophthora infestans, the cause of late blight of potato (9). In the case of soybean rust, herbarium specimens collected from many locations are available, some dating from the 1800s. Molecular diagnostic methods now exist (3) that employ quantitative PCR (qPCR) for the detection, differentiation, and quantification of the two species, and additional phylogenetic studies have utilized SSR fragment analysis $(1,12)$ to make inferences on the genetic structure of what is essentially a clonal population of isolates. As a prelude to further molecular studies on the genetic structure of world populations of soybean rust using simple sequence repeat (SSR) markers (1), our objective was to use the herbarium specimens in our analyses to answer the simple question of whether it was possible to extract adequate useful DNA from the preserved fungal structures to perform species distribution studies over geographical space and time.

\section{Materials and Methods}

Thirty-eight samples of dried archival leaf tissue, which had been reported to contain Phakopsora spp., were sampled on location at the Arthur Herbarium at Purdue University, West Lafayette, Indiana (Table 1). All accessions were numerically identified along with the host genus (and usually species), and in most cases the year of collection was indicated along with a geographic location. The dried, pressed specimens had been stored at ambient herbarium temperature in the years (or decades) since collection in pouches of folded herbarium paper. Specimens were handled with clean forceps and examined under a dissecting microscope to locate uredinia characteristic of Phakopsora. Using a sterile scalpel, a segment of tissue 1 to $2 \mathrm{~cm}^{2}$ containing uredinia was excised and placed in a sterile tube. Forceps were cleaned and gloves and scalpel blades were changed between herbarium accession pouches. Samples were transported to the Soybean Disease Laboratory at the University of Illinois.

All samples were photodocumented under a dissecting microscope (Fig. 1) taking equivalent care to preclude cross-contamination during handling, and then transferred to extraction tubes. DNA was extracted from the entirety of each sample using the FastDNA Spin kit with Lysing Matrix A and buffer CLS-VF with PPS (one of several extraction buffer options provided with the kit), as directed by the manufacturer (Qbiogene, Carlsbad, CA; now MP Biomedicals, Solon, $\mathrm{OH}$ ). One microliter of sheared salmon sperm DNA (Applied 
Biosystems/Ambion, Austin, TX) at a concentration of $1 \mu \mathrm{g} / \mu \mathrm{l}$ was added to the extraction tube with the tissue to act as a carrier in anticipation of recovery of only trace quantities of nucleic acids. Tissue disruption occurred in the FastPrep FP-120 homogenizer (Bio 101Thermo Electron Corp.; now MP Biomedicals, Solon, OH) for $40 \mathrm{~s}$ at a speed setting of $6 \mathrm{~m} / \mathrm{s}^{2}$. The aqueous eluate $(100 \mu \mathrm{l})$ from the spun columns was diluted 50 -fold with a diluent containing $5 \mathrm{mM}$ Tris, $\mathrm{pH} 8$, and $1 \mu \mathrm{g} / \mathrm{ml}$ salmon DNA. Five $\mu \mathrm{l}$ of the diluted DNA was assayed by multiplexed quantitative PCR (qPCR) in duplicate reactions.

qPCR assays used a Stratagene (Agilent Technologies, Santa Clara, CA) Mx3005p real-time thermal cycler and Invitrogen Platinum qPCR Supermix-UDG (Life Technologies Corp., Carlsbad, CA) in a $25 \mu 1$ reaction volume. Reactions provided a final $\mathrm{Mg}^{2+}$ concentration of $7 \mathrm{mM}$ and included $50 \mathrm{nM}$ ROX dye as a passive reference. Oligonucleotide PCR primers specific to P. pachyrhizi or P. meibomiae, and a fluorogenic 5 '-exonuclease linear hydrolysis probe, were commercially synthesized (IDT, Coralville, IA) according to the multicopy 5.8S and ITS2 rDNA target sequences (Ppm1, Ppa2, and Pme2, FAM probe) previously published (3). The qPCR thermal profile consisted of an initial uracil deglycosylase (UDG) incubation at $60^{\circ} \mathrm{C}$ for $2 \mathrm{~min}$, then a $95^{\circ} \mathrm{C}$ denaturation/activation incubation for $2 \mathrm{~min}$, followed by 40 cycles of $15 \mathrm{~s}$ at $95^{\circ} \mathrm{C}$ and $30 \mathrm{~s}$ at $60^{\circ} \mathrm{C}$. The $\mathrm{Mx} 3005 \mathrm{p}$ was programmed for an adaptive baseline and automatic cycle thresholds, based upon dRn. Fifty ymol (30 copies) of an exogenous control target (PpaIC or PmeIC) was coamplified in every tube, as a multiplex reaction using the coreIC-Cy5 probe, to validate any negative results for both assays, as previously described (4). The UDG component of the supermix prevented false-positive results from adventitious contamination of reagents by amplicon of previous reactions. We previously demonstrated single-spore detection sensitivity with the Ppa assay (unpublished). All laboratory disposables were DNA-, RNA-, DNase-, and RNase-free; pipet tips included aerosol barrier filters.

A reference DNA to create standard curves for absolute quantification was extracted (FastDNA Spin Kit, manufacturer's directions) from a suspension of freshly heat-killed $\left(50^{\circ} \mathrm{C}\right.$ for $\left.12 \mathrm{~h}\right) P$. pachyrhizi isolate FL07-1 urediniospores (counted in a hemocytometer), and serially diluted. DNA of Puccinia polysora (the fungus causing southern corn rust) was also extracted. Urediniospores of $P$. polysora were a generous gift of J.K. Pataky (Department of Crop Sciences, University of Illinois, Urbana). These standard curves ranged from 500 to 0.05 spore-equivalents, and typically gave a $\mathrm{RSq}$ of greater than 0.995 and an efficiency of over $95 \%$. DNA of P. meibomiae was the generous gift of R. Frederick (USDA-ARS, Ft. Detrick, MD) and used at a concentration of $1 \mathrm{pg} / \mu \mathrm{l}$.

An additional qPCR assay ("all-rust") was designed to be more inclusive of additional rust species, targeting the rRNA large subunit gene. To design the all-rust assay, DNA sequences from five Phakopsora species and two Puccinia species (Table 2) were aligned using the Clustal

Table 1. Herbarium specimens (Arthur Herbarium at Purdue University) used to determine if the sample was Phakopsora pachyrhizi or P. meibomiae based on quantitative PCR primers specific to $P$. pachyrhizi, P. meibomiae, or to a third group inclusive of many rust species

\begin{tabular}{|c|c|c|c|c|c|}
\hline Accession & Label identity & Year & Location & Host & Diagnosis \\
\hline F12125 & P. pachyrhizi & 1931 & Ishikawa, Japan & Glycine $\max$ & $\overline{P . \text { pachyrhizi }}$ \\
\hline N5555 & P. pachyrhizi & 2006 & Indiana, USA & G. $\max$ & P. pachyrhizi \\
\hline F18518 & P. pachyrhizi & 1971 & Queensland, Australia & G. $\max$ & P. pachyrhizi \\
\hline F14033 & P. pachyrhizi & 1932 & Kiangsi Prov., China & Pueraria & P. pachyrhizi \\
\hline N4663 & P. pachyrhizi & 1994 & Hawaii, USA & G. $\max$ & P. pachyrhizi \\
\hline F1167 & P. pachyrhizi & 1924 & Mindanao, Philippines & Pueraria & P. pachyrhizi \\
\hline $66727^{\mathrm{a}}$ & P. pachyrhizi & 1913 & Taipei, Taiwan & Pachyrhizus & P. pachyrhizi \\
\hline N4510 & P. pachyrhizi & 2006 & Indiana, USA & G. $\max$ & P. pachyrhizi \\
\hline N4662 & P. pachyrhizi & 1994 & Hawaii, USA & G. $\max$ & P. pachyrhizi \\
\hline F14028 & P. pachyrhizi & 1932 & Kiangsi Prov., China & G. $\max$ & P. pachyrhizi \\
\hline F1164 & P. pachyrhizi & 1912 & Kawauye-mura, Japan & G. $\max$ & P. pachyrhizi \\
\hline 64283 & P. pachyrhizi & 1971 & Jalisco, Mexico & Desmodium & P. meibomiae \\
\hline 88336 & P. pachyrhizi & 1983 & Veracruz, Mexico & Pachyrhizus & P. meibomiae \\
\hline N4795 & Phakopsora & 1983 & Minas Gerais, Brazil & G. $\max$ & P. meibomiae \\
\hline 66693 & P. pachyrhizi & 1980 & Minas Gerais, Brazil & Macroptillium & P. meibomiae \\
\hline N4579 & Phakopsora & 1983 & Minas Gerais, Brazil & Glycine & P. meibomiae \\
\hline 87670 & Phakopsora & $\mathrm{NP}^{\mathrm{d}}$ & NP & Macroptillium & P. meibomiae \\
\hline 89658 & P. pachyrhizi & 1988 & Minas Gerais, Brazil & Phaseolus & P. meibomiae \\
\hline N4796 & Phakopsora & 1983 & Minas Gerais, Brazil & Glycine & P. meibomiae \\
\hline 66715 & P. pachyrhizi & 1928 & Sao Paulo, Brazil & G. $\max$ & P. meibomiae \\
\hline 87221 & Phakopsora & 1983 & Minas Gerais, Brazil & Phaseolus & P. meibomiae \\
\hline F1174 & P. pachyrhizi & 1923 & Lingayen, Philippines & Crotalaria & P. meibomiae \\
\hline $\mathrm{F} 1181^{\mathrm{b}}$ & P. pachyrhizi & 1923 & Mt. Arayat, Philippines & Derris & P. meibomiae \\
\hline 66707 & P. pachyrhizi & 1978 & Sao Paulo, Brazil & Neonotonia & P. meibomiae \\
\hline 87293 & P. pachyrhizi & 1983 & Sao Paulo, Brazil & Neonotonia & P. meibomiae \\
\hline N4309 & P. pachyrhizi & 1986 & Brazil & Dolichos & P. meibomiae \\
\hline 66231 & P. meibomiae & 1980 & Veracruz, Mexico & Erythrina & Negative \\
\hline F16214 & P. pachyrhizi & 1949 & Sierra Leone & Erythrina & Negative \\
\hline F16212 & P. pachyrhizi & 1957 & Ghana & Vigna & Negative \\
\hline F14027 & P. pachyrhizi & 1931 & Anhwei Prov., China & G. $\max$ & Negative \\
\hline 90151 & Phakopsora & 1986 & Minas Gerais, Brazil & Eriosema & Negative \\
\hline 89763 & P. pachyrhizi & 1887 & Tonkin, Vietnam & Pachyrhizus & Negative \\
\hline N3870 & P. pachyrhizi & 1979 & Tanzania & Vigna & Other \\
\hline $3239^{c}$ & P. pachyrhizi & NP & Isle of São Tomé, Africa & Vigna & Other \\
\hline 3240 & Phakopsora & 1917 & Herradura, Cuba & Teramnus & Other \\
\hline 14035 & P. pachyrhizi & 1933 & Kwangsi Prov, China & Shuteria & Other \\
\hline 66900 & P. pachyrhizi & 1982 & Nsukka, Nigeria & Erythrina & Other \\
\hline F16211 & P. pachyrhizi & 1946 & Sierra Leone & Vigna & Other \\
\hline
\end{tabular}

\footnotetext{
a Type of $P$. pachyrhizi Sydow (http://plants.jstor.org/specimen/pur004212?s=t)

b Type of $P$. calothea Syd. (http://plants.jstor.org/specimen/pur004213?s=t)

c Type of Uredo vignae Bres. (http://plants.jstor.org/specimen/pur004211?s=t)

${ }^{\mathrm{d}}$ Information was not available for the specimen.
} 
$\mathrm{W}$ algorithm, and conserved sequences were identified and tested for functionality and selectivity, and a suitable set chosen which amplified $P$. pachyrhizi, $P$. meibomiae, and P. polysora, but neither salmon nor soybean DNA. The two primers were: ARF1 (5'-GTTGTTTGGGAATG
CAGC-3') and ARR3 (5'-CATCTTTCCCTCACGGTA-3') and both were used at a final, optimized concentration of $300 \mathrm{nM}$ in the assay. The probe was ARP1, synthesized (IDT) with a FAM reporter and an Iowa Black quencher (5'-FAM-CAAAGTGGGTGGTAAATTCCATC
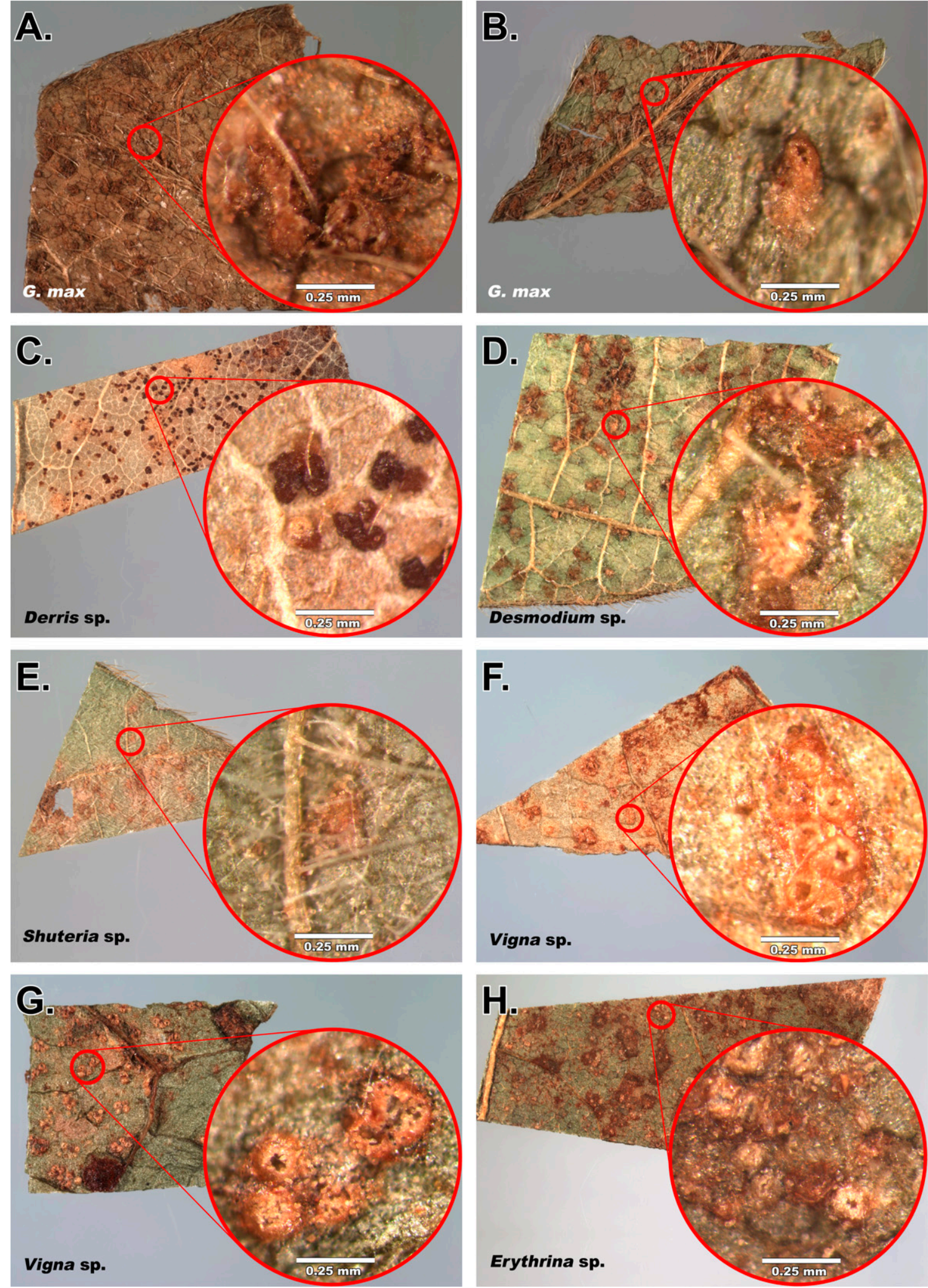

Fig. 1. Selected leaf samples (Arthur Herbarium at Purdue University $=$ PUR) from which DNA was extracted; host plant as indicated; scale bar $=250 \mu \mathrm{m}$ in the inset photo. All specimens had evidence of rust infection, including uredinia and residual urediniospores. A and B were found to contain DNA from P. pachyrhizi. A, Japan (1912; PUR accession F1164); B, Hawaii (1994; PUR accession N4662). C and D were found to contain DNA from P. meibomiae. C, Philippines (1923; PUR accession F1181); D, Mexico (1971). E, F, G and $\mathrm{H}$ were found to be positive for the presence of a rust, but were negative for both P. pachyrhizi and P. meibomiae. E, China (1933; PUR accession 14035); F, Tanzania (1979; PUR accession N3870); G, Sierra Leone (1946; PUR accession F16211); H, Nigeria (1982; PUR accession 66900). 
TAAGGC-IAB-3'), which was used at a final, optimized concentration of $100 \mathrm{nM}$ in the assay with $5 \mathrm{mM} \mathrm{Mg}{ }^{2+}$. Primers and HEX-labeled probe for the HHIC multiplexed exogenous control assay, along with $50 \mathrm{ymol}$ of linearized pJSH-B14 plasmid target (plasmid no. 20145 at addgene. org), were included in each reaction to validate negative results (4).

\section{Results}

DNA of $P$. pachyrhizi was successfully obtained and quantified by qPCR from many archival tissues, some quite old, including a specimen of soybean collected in Japan in 1912 (Fig. 1A). The yield of $P$. pachyrhizi DNA obtained from each accession is shown in Table 3, and the highest yield was from a 1913 Taiwanese accession, obtaining over 6,000 urediniospore-equivalents (SEq) of DNA. We have determined that 2 to $3 \mathrm{SEq}$ of DNA is the minimum necessary for each of our SSR analyses (unpublished) and thus, to run four primer pairs in duplicate, approximately 25 SEq of DNA is required for each of our intended SSR analyses. Several of these archival specimens did, in fact, yield sufficient DNA for SSR analyses, demonstrating the potential for archival specimens to facilitate molecular genetic studies. Although estimated as SEq of DNA, this assay does not discriminate between $P$. pachyrhizi DNA from mycelium, haustoria, urediniospores, or other fungal structures, nor do these assays discern living from dead cells. The diagnostic result of each specimen tested is shown in Table 1. Eleven of the 38 specimens were found to contain P. pachyrhizi and not P. meibomiae; they dated from 1912 to 2006. Fifteen specimens were found to contain $P$. meibomiae and not P. pachyrhizi; they dated from 1923 to 1988 (e.g., Fig. 1C and D). Half of the remaining 12 specimens, which were negative for both $P$. pachyrhizi and P. meibomiae, were found to amplify in the all-rust assay, indicating presence of rust DNA belonging to another species (Fig. 1E to H). These specimens were collected from Tanzania (1979), Nigeria (1982), São Tomé, China (1933), and Sierra Leone (1946), and none of them were from soybean. The final six specimens contained no amplifiable DNA and were inconclusive; they dated from 1887 to 1980 . No $P$. pachyrhizi was observed in any specimen from Africa; however, P. meibomiae was determined in two 1923 specimens from the Philippines, and one unidentified rust was observed in the 1933 specimen from China. The positive and negative

Table 2. Rust species for which rRNA large subunit DNA sequences were aligned in the design of the all rust qPCR assay

\begin{tabular}{ll}
\hline GenBank Accession No. & \multicolumn{1}{c}{ Species } \\
\hline DQ354537 & Phakopsora pachyrhizi \\
AB354766 & P. vitis \\
AB354753 & P. euvitis \\
AB354760 & P. meliosmae \\
DQ354535 & P. tecta \\
AY114289 & Puccinia graminis f. sp. tritici \\
DQ460729 & P. striiformis f. sp. hordei \\
\hline
\end{tabular}

Table 3. Yield of Phakopsora pachyrhizi DNA obtained, for those specimens (Arthur Herbarium at Purdue University) containing this species. Amounts are the estimated total amount of $P$. pachyrhizi DNA recovered from the entire specimen, expressed as urediniospore equivalents (SEq), corrected for dilution, to two significant figures

\begin{tabular}{lc}
\hline Accession No. & Yield (SEq) \\
\hline 66727 & 6,100 \\
N4662 & 1,900 \\
F12125 & 500 \\
N4663 & 260 \\
F14028 & 130 \\
N4510 & 90 \\
F1164 & 53 \\
N5555 18518 & 53 \\
F1167 & 26 \\
F14033 & 11 \\
& 8 \\
\hline
\end{tabular}

control reactions run with each experiment gave the expected positive or negative result (data not shown), and the multiplexed internal control reactions successfully validated all negative reactions, affirming the functionality of the reaction cocktail and the absence of inhibitors or mechanical, instrument, or analyst error.

\section{Discussion}

Herbarium specimens dating from 1887 to 2006 were used to detect the soybean rust fungi, $P$. pachyrhizi and $P$. meibomiae. Of the 38 archival specimens, 11 were positive for $P$. pachyrhizi, including a 1912 specimen from Japan, but no $P$. pachyrhizi was found in specimens before 1994 outside of Asia or Australia, indicating that $P$. pachyrhizi was confined to the Eastern Hemisphere (8). Fifteen specimens were positive for $P$. meibomiae, including a 1928 specimen from Brazil and two 1923 specimens from the Philippines. This is the first report of $P$. meibomiae occurring outside the Western Hemisphere (8). Because the samples were destructively extracted, and because it is unlikely that the 85 -year-old specimen material remaining in the herbarium would contain viable urediniospores, it is not possible to perform Koch's postulates to support this observation. However, sequencing or immunoassay tests beyond the scope of this manuscript could be attempted. The world distribution of $P$. meibomiae remains unknown, as well as its primary host. The species likely evolved with legumes, and its distribution is somewhat known in the Western Hemisphere, but nothing is known about its distribution elsewhere other than our finding it in herbarium specimens from the Philippines. Without further worldwide sampling, questions will remain about the hosts and distribution of $P$. meibomiae outside the Western Hemisphere. The answers may reveal potential genetic or cultivational solutions for disease management of both species.

Interestingly, there were six specimens found to contain some species of rust not being $P$. pachyrhizi or $P$. meibomiae, although uredinia were present (Fig. 1E to $\mathrm{H}$ ) and historical examination had suggested a tentative identity of $P$. pachyrhizi. These may represent one or more formae specialis, or entirely separate species of Phakopsora. None of these were from G. max; three were on species of Vigna, and one each on Erythrina, Teramnus, and Shuteria. An alternative explanation could be that the available qPCR assays for $P$. pachyrhizi and P. meibomiae are not completely inclusive, as they were developed based upon sequence data from a limited number of isolates. Thus, one or both of the target species may not have been fully detected because of undetermined variation. The same complaint may be lodged against many molecular diagnostic assays for plant pathogens; however, those assays remain useful until anomalies are observed, at which point they can be improved. Whether such variation existed or still exists in Phakopsora spp. is unknown, and is a reasonable point of inquiry for future research. There were six more specimens that were negative in every assay and probably represent instances in which all DNA had degraded over time, as a result of preservation, harsh storage conditions during transportation, or other environmental factors, and include not only the sample collected on the eponymous Pachyrhizus species in 1887 in Vietnam, but also the sample collected almost a hundred years later on Erythrina, in 1980 in Veracruz, Mexico. There was no apparent correlation between the age of samples and the yield of rust DNA obtained in this experiment, as the highest yield came from a 1913 Taiwanese specimen, while the secondhighest yield came from a 1994 Hawaiian sample (Table 3). However, note that no attempt was made to sample equivalent numbers of uredinia.

It is interesting to note that there was no overlap in the molecular identification of any of the specimens determined in this study to be of the Phakopsora; i.e., no specimen positive for P. pachyrhizi was also positive for $P$. meibomiae or vice versa. This could be of significance pathologically since it points to the fact that $P$. pachyrhizi and $P$. meibomiae may have moved or occurred beyond their initially defined geographical boundaries, and also from the perspective of sample integrity. Unknown and possibly considerable numbers of other workers over the last century have had the opportunity to examine and sample from these herbarium specimens, and certainly it has been possible that residue (urediniospores, tissue fragments, etc.) could have been inadvertently transferred between herbarium pouches. Although we did not examine any host specimens that 
explicitly claimed not to be infected with rust, it would seem that we were not alone in exercising caution to prevent carryover from contaminating this valuable collection.

This study demonstrates that the identities of $P$. pachyrhizi and $P$. meibomiae, and possibly other rust species, are determinable by molecular genetic analysis of residue from dried host tissue specimens, some quite old, housed in herbaria without chemical or cryopreservation. Further, the DNA recovered can be of adequate quality for qPCR amplification and quantification, and in the amounts necessary for further genetic studies, such as SSR genotyping. While the geographic and temporal scope of this study was limited by the material available, the findings regarding the presence of $P$. meibomiae in the far east are novel; as additional archival materials become accessible, these results will be readily expanded. The careful curation of herbaria by past botanical scholars has created a legacy of unexpected utility for modern investigations that will help to further our understanding of fungal distribution and genetic diversity, which may be applied over time for practical benefit to agriculture and society.

\section{Acknowledgments}

We are grateful to the Arthur Herbarium at Purdue University for allowing us access to, and sampling of, the rust collection for this analysis. David A. Smith and Tara L. Slaminko assisted in the specimen selection and sampling.

\section{Literature Cited}

1. Anderson, S. J., Stone, C. L., Posada-Buitrago, M. L., Boore, J. L., Neelam, B. A., Stephens, R. M., Luster, D. G., Frederick, R. D., and Pedley, K. F. 2008. Simple sequence repeat markers for differentiating and evaluating genetic diversity of soybean rust isolates. Mol. Ecol. Resour. 8:1310-1312.

2. Farr, D. F., and Rossman, A. Y.2011. Fungal Databases, Systematic Mycology and Microbiology Laboratory, ARS, USDA. Retrieved July 28, 2014, from http://nt.ars-grin.gov/fungaldatabases/
3. Frederick, R. D., Snyder, C. L., Peterson, G. L., and Bonde, M. R. 2002. Polymerase chain reaction assays for the detection and discrimination of the soybean rust pathogens Phakopsora pachyrhizi and $P$. meibomiae Phytopathology 92:217-227.

4. Haudenshield, J. S., and Hartman, G. L. 2011. Exogenous controls to increase negative call veracity in multiplexed, quantitative PCR assays for Phakopsora pachyrhizi. Plant Dis. 95:343-352.

5. Loockerman, D. J., and Jansen, R. K. 1996. The use of herbarium material for DNA studies. Pages 205-220 in: Sampling the Green World. T. F. Stuessy and S. H. Sohmer, eds. Columbia University Press, New York.

6. Mesquita, N., Portugal, A., Videira, S., Rodríguez-Echeverría, S., Bandeira, A., Santos, M., and Freitas, H. 2009. Fungal diversity in ancient documents A case study on the Archive of the University of Coimbra. Int. Biodeter Biodegr. 63:626-629.

7. Murithi, H. M., Beed, F. D., Madata, C. S., Haudenshield, J. S., and Hartman, G. L. First report of Phakopsora pachyrhizi on soybean causing rust in Tanzania. Plant Dis. 98:1586.

8. Ono, Y., Buritica, P., and Hennen, J. F. 1992. Delimitation of Phakopsora, Physopella and Cerotelium and their species on Leguminosae. Mycol. Res. 96:825-850.

9. Ristaino, J. B. 2002. Tracking historic migrations of the Irish potato famine pathogen, Phytophthora infestans. Microbes Infect. 4:1369-1377.

10. Slaminko, T. L., Miles, M. R., Frederick, R. D., Bonde, M. R., and Hartman, G. L. 2008. New legume hosts of Phakopsora pachyrhizi based on greenhouse evaluations. Plant Dis. 92:767-771.

11. Slaminko, T. L., Miles, M. R., Marois, J. J., Wright, D. L., and Hartman, G. L. 2008. Hosts of Phakopsora pachyrhizi identified in field evaluations in Florida. Online. Plant Health Prog. doi:10.1094/PHP-2008-1103-01-RS

12. Twizeyimana, M., Ojiambo, P. S., Haudenshield, J. S., Caetano-Anollés, G. Pedley, K. F., Bandyopadhyay, R., and Hartman, G. L. 2011. Genetic structure and diversity of Phakopsora pachyrhizi isolates from soyabean Plant Pathol. 60:719-729.

13. Vittal, R., Yang, H., and Hartman, G. L. 2012. Anastomosis of germ tubes and nuclear migration of nuclei in germ tube networks of the soybean rust pathogen, Phakopsora pachyrhizi. Eur. J. Plant Pathol. 132:163-167. 